\title{
Emergence through branching and evolution
}

\author{
The automation industry in Penang, Malaysia
}

\begin{abstract}
Evolutionary economic geography proposes regional branching as a mode of industry emergence and development. It is claimed that branching enhances performance and evolution. In this article we investigate the relevance of regional branching and this claim in the context of Southeast Asia's late-industrialization. We report research into the industrial automation industry in Penang, Malaysia. We first demonstrate that the emergence of this industry conforms well to regional branching. We show that despite this mode of genesis, industry development has stalled at an early stage and its evolution shows bifurcation: amongst the firms there are growers but also and substantially more - stagnators. We offer a framework for understanding regional branching in late-industrialization context and for understanding differential performance/evolution. Applying this framework to our research context we find that regional branching, stalling, and the occurrence of stagnators and only a few growers can be understood from factors and hampering/conducive circumstances at the levels of the industry, the region and individual firms.
\end{abstract}

Keywords: regional branching, automation industry, evolution, Penang, Malaysia

\section{Introduction}

The genesis and development of industries in economic spaces of emerging countries that are experiencing 'late' industrialization is part of the spatial evolution of industries on an international scale. While the common industry life cycle model can be used here as an 'anchor' to approach industry evolution - whereby this evolution is marked by individual stages from initial (embryonic and take-off), growth, mature, to decline, distinguished on the basis of a set of structural parameters (KÖNIG/STEPHAN 2007) - with respect to late-industrializing spaces the cycle may be adapted in view of characteristics of the initial and growth stages that differ from the archetype. Relevant literature emphasizes two modes of genesis: exogenous implantation through the attraction of foreign firms engaged in international production relocation, and endogenous development through 'create and grow' whereby an entrepreneurial state concerns itself with technological resources, learning, and market(s) (see for example BUNNELL 2004; HAGGARD et al. 1998; JOMO 2001, 2003; KIM 1999, 2001; LALL/URATA 2003; Lee Keun 2010; Mathews 1999, SunG/ CARLSSON 2003; ZYSMAN/DOHERTY 1995).
Evolutionary economic geography (EEG) has developed important new ideas on industry genesis and evolution (e.g. BOSCHMA/FRENKEN 2009). It privileges the autonomous incrementality of the development of firms, entry from seedbeds in locations, and incremental capability development. Seedbeds often are part of the existing industry base; firms in new industries need not be new firms. Conceptions of entrepreneurship underly evolutionary industry development. Besides related/unrelated local variety and technological relatedness, BoschMA/ FRENKEN (2009) offer the notion of regional branching which denotes that new variety is rooted in technologically related activities in a region. This is a growth path that regions should favour.

Research on regional branching as a mode of emergence of new industry in late-industrialization contexts is still scarce. Yet it is relevant because first, knowledge about the conditions that are conducive for branching to occur is still deficient. Second, there is the notion that success or failure, or rather performance after emergence, of an industry is related to the mode of its genesis. A case in point is the 'cre- 
ate and grow' industry birth and evolution. Although in the context of late-industrialization this formula has achieved successes (e.g. South Korea's mobile phone/wireless industry), it has been discredited by now, due to factors hampering success in the longer run (HIRA/MORFOPOULOS/CHEE 2012). While BosCHMA/FrENKEN (2009) hold that regional branching enhances local industry performance, there is a need to scrutinize it in the context of late-industrialization, to establish its validity and - again - to identify the conditions governing positive performance, or perhaps the contrary.

This article considers the evolution of the automation industry in Penang (Malaysia), propelled by local firms, from its inception in the mid-1990s up to the end of the last decade. We report a two-point study of the industry. The initial research, carried out in mid-2005, examined the genesis of the industry and its drivers, as well as initial growth in the local context. The follow-up study - carried out in 2011 - focussed on entry/exit and performance of firms since 2005 and the explanatory factors. The first goal of the analysis here is to demonstrate branching as mode of genesis of the industry and to identify the enabling conditions in local context. The second goal is to outline postemergence industry life cycle evolution in the light of EEG claims, and to analyse the conditions underlying this evolution.

The discussion is organized as follows. In the next section we elaborate the framework guiding the analysis of the evolution of Penang's automation industry. Then we briefly discuss research methodology. Subsequently, we deal with the genesis and initial phase of development of the industry and the conditions underlying the mode of emergence, following which the recent evolution of the industry will be discussed accompanied by an interpretation of the performance observed. We conclude by offering some views on the quality of the framework devised for this study.

\section{Framework}

Regional branching from existing industries in the same family occurs in two ways, a new industry grows out of an old one; or a new industry is the outcome of recombination of competences from different industries (BOSCHMA/ FRENKEN 2009). Following KLEPPER (2001a, 2001b, 2002), a new branch develops from 1) pre-existing firms diversifying from related products and/or activities, 2) new firms founded by entrepreneurs who headed firms in the same related industries, and 3) new firms founded by former employees of firms in client industries. The first two categories involve experienced entrepreneurs who are carriers of knowledge spillovers and routine replication. The third category are de novo spin-offs.

While there are knowledge gaps concerning the conditions conducive to branching, local branching is increasingly seen to guarantee industry success. Earlier KLEPPER (2001a) associated this with characteristics of entrepreneurs and firms at the start and take-off of a new branch. However, recent literature suggests that success is subject to positive conditions, in the absence of which growth of firms or activities spawned by branching is hampered. Knowledge gaps especially prevail in (Asian) late-industrialization contexts.

This framework concerns conditions underlying emergence through branching and successful evolution of branched industries upon emergence derived from first, literature on industry life cycle and/or factors underlying success and/or failure of industries and firms in advanced countries (e.g. BREZNITZ 2005, 2007; Buenstorf 2007, FritsCh/SCHINDELE 2010; KLEPPER 2001A, 2001B, 2002; KÖNIG/STEPHAN 2007, SANTARELli/VivarelLi 2007) and second, from literature on East and Southeast Asia that considers industry genesis, evolution and learning in late-industrialization (e.g. JOMO 2003, KIM 1999, 2001; LeE/SAXENIAN 2007; Lee Keun 2010; Masuyama et al. 2001; Sung/ CARLSSON 2003). In their study of firm survival in German manufacturing, FRITSCH/SCHINDELE (2010) suggest three interlocking sets of determinants of success/failure, namely at the levels of the firm (business), industry and region. Our framework employs this categorization as an organizational device. Below we discuss each category taking into account features of late-industrialization in Asian countries. KöNIG/ STEPHAN (2007) emphasize uncertainty, as to the size and structure of the market (see also KLEPPER/MALERBA 2010), and product quality as competences of suppliers are uncertain. If unresolved they become liabilities hampering evolution. From here we can consider conditions surrounding branching and post-emergence branch evolution. As to branching, fac- 
Tab. 1: Factors and circumstances at regional level conducive or less conducive to branching, resolving uncertainties and branch evolution

\begin{tabular}{|c|c|c|}
\hline Factor & Conducive & Less conducive or liability \\
\hline $\begin{array}{l}\text { Local product } \\
\text { demand: size and } \\
\text { structure }\end{array}$ & $\begin{array}{l}\text { Above critical mass; diverse; } \\
\text { Evolution: no reliance on export of } \\
\text { low-end products }\end{array}$ & $\begin{array}{l}\text { Not above critical mass; narrow; } \\
\text { Evolution: increasing reliance on } \\
\text { export of low-end products }\end{array}$ \\
\hline Labour market & Not strained; acceptable costs & Strained; high costs \\
\hline $\begin{array}{l}\text { Local industry / } \\
\text { Local supplier } \\
\text { base }\end{array}$ & $\begin{array}{l}\text { Branching: strong base of (support) } \\
\text { industries } \\
\text { Branch evolution: local supplier base } \\
\text { Both: wide, high competences and } \\
\text { quality }\end{array}$ & $\begin{array}{l}\text { Branching: weak base of (support) } \\
\text { industries } \\
\text { Branch evolution: weak local supplier } \\
\text { base } \\
\text { Both: narrow, low competences and } \\
\text { quality }\end{array}$ \\
\hline Business system & SME dominance & $\begin{array}{l}\text { Few large enterprises and many small } \\
\text { firms }\end{array}$ \\
\hline $\begin{array}{l}\text { Regional systemic } \\
\text { coordination }\end{array}$ & $\begin{array}{l}\text { Especially in branch evolution: } \\
\text { critical mass of state assistance in } \\
\text { resolving industry issues; dedicated } \\
\text { institutional platforms; industry } \\
\text { policy; industry cluster; collective } \\
\text { action with broad participation; } \\
\text { co-evolution in growth phase }\end{array}$ & $\begin{array}{l}\text { Especially in branch evolution: little } \\
\text { state assistance in resolving industry } \\
\text { issues; no institutional platforms; no } \\
\text { industry policy; no functioning } \\
\text { industry cluster or collective action, or } \\
\text { low participation; no co-evolution in } \\
\text { growth phase }\end{array}$ \\
\hline $\begin{array}{l}\text { Regional } \\
\text { technological } \\
\text { environment }\end{array}$ & $\begin{array}{l}\text { Especially in branch evolution: well } \\
\text { functioning innovation system in part } \\
\text { directed to the industry; critical mass } \\
\text { of innovation; potential to source } \\
\text { knowledge from actors in system but } \\
\text { outside the industry; collective } \\
\text { innovation and inter-firm spillovers; } \\
\text { local technology policy; co-evolution } \\
\text { in growth phase }\end{array}$ & $\begin{array}{l}\text { Especially in branch evolution: } \\
\text { fragmented innovation system not } \\
\text { directed to the industry; little } \\
\text { innovation; little potential to source } \\
\text { knowledge from actors in system but } \\
\text { outside the industry; little collective } \\
\text { innovation and no inter-firm } \\
\text { spillovers; no local technology policy; } \\
\text { no co-evolution in growth phase }\end{array}$ \\
\hline
\end{tabular}

Source: own draft

tors related to region and industry are accorded prime significance, while all three sets are important with respect to post-emergence branch evolution.

Tab. 1 lists factors at the regional level and presents the differentiation of related circumstances. Local demand and a base of small and medium sized firms (SME) in - support - industries dealing with technologically related products possessing a sufficient foundation of competences and some degree of systemic coordination promote branching. Post-emergence evolution benefits from critical mass in the regional technological environment (DUTRÉNIT/ TEubal 2010; KÖNIG/STEPHAN 2007), produced through a well-functioning innovation system. Such an innovation system may rely on public or semi-public institutions, including links between industry and educational institutions. Where late-industrialization is driven by multinational corporations (MNC), these may constitute a significant avenue of technology sourcing in an innovation system. With respect to both branching and post-emergence evolution a further contributory factor is endowment with a local supply of related entrepreneurial activity, knowledge externalities and skilled labour (Boschma/FrenKen 2009). As to elements included in the first part of Tab.1, the literature has addressed co-evolution (BREZNITZ 2005, 2007; CARMEY/GEDAJLOVIC 2002; HIRA/ Morfopoulos/Chee 2012; Malerba 2006; Dutrénit/Teubal 2010; LeE/SAXenian 2007; WENTING/FrENKEN 2011), supporting the view that both co-evolution of the local/regional technological and institutional environment and regional systemic coordination are impor- 
Tab. 2: Factors and circumstances at (local) industry level conducive or less conducive to branching, resolving uncertainties and branch evolution

\begin{tabular}{ll} 
Factor & Conducive \\
\hline Product(s) and & Branching: product heterogeneity, \\
processes & $\begin{array}{l}\text { low end products homogeneous } \\
\text { architecture and simple, } \\
\text { customization }\end{array}$ \\
& Branch evolution: higher-end \\
products still homogeneous \\
architecture and simple; higher \\
degree of standardization; markets, \\
also higher-end, rather diverse and \\
standard; product configurations and \\
standards transferable between \\
clients or industries
\end{tabular}

$\begin{array}{ll}\text { Technological } & \text { Branching: low technology } \\ \text { regime } & \text { requirements } \\ & \text { Especially in branch evolution: rather } \\ & \text { standard; supply-driven }\end{array}$

Role innovation
Less conducive or liability

Branching: product homogeneity, even low-end products complex systemic architecture; little customization Branch evolution: higher-end products complex systemic architecture; modular requiring many (external) inputs; high degree of customization; markets potentially diverse but higher-end products need adaptation; product configurations and standards not easily transferable between clients or industries

Branching: high technology requirements

Especially in branch evolution: custom and demand-driven

Both branching and branch evolution: Both branching and branch evolution: weak/little; technology development slow; slow shift of frontier strong/significant; technology development fast; rapid shift of frontier

Local firm structure; global Both branching and branch evolution: Both branching and branch evolution: firm structure many equal firms; global: distributed structure without clear lead firms; no market domination a few dominant firms and many small firms; global: a limited number of large lead firms controlling supplydriven markets

\begin{tabular}{lll}
\hline Ties with & Branching: strong & Branching: strong or weak \\
dominant (local) & Branch evolution: weaker & Branch evolution: strong
\end{tabular}
client(s)

Source: own draft

tant in the growth phase of emerging industries in late-industrializing spaces.

The absence of such co-evolution is likely to prematurily drive an emerging industry in lock-in in a low-end path. Systemic coordination is deemed functional to co-evolution. Agencies of state and inter-firm collaboration allow market imperfections to be overcome. The absence of coordination may engender or reinforce institutional, cognitive, or other types of lock-in (WENTING/FrENKEN 2011).

Tab. 2 depicts factors at the industry level and differentiates circumstances related to these factors that are conducive from those that constitute liabilities. Product(s) and processes, technological regime and the role of innovation are interrelated to a large extent. Features of these with respect to a specific industry determine the local technological system that has to be present or built for the industry to thrive locally. Industries vary significantly in these aspects. The role of the technological regime of an industry has been elaborated in a wide-ranging literature, part of which also deals with late-industrializing regions (summarized in KIM/LeE 2003; LeE KeUn 2010). Besides differentially requiring a local technological system, the technological regime translates into selection of firms of specific organizational form growing the industry locally. From this perspective, some industries are more prone to emergence through branching than others and 
Tab. 3: Factors and circumstances at firm level conducive or less conducive to branching, resolving uncertainties and branch evolution

\begin{tabular}{|c|c|c|}
\hline Factor & Conducive & Less Conducive or Liability \\
\hline Size & Large & Small \\
\hline Origin & Local & Foreign \\
\hline Background founder & $\begin{array}{l}\text { Established entrepreneur; former } \\
\text { employee client industry; related } \\
\text { industry }\end{array}$ & $\begin{array}{l}\text { New entrepreneur; unrelated } \\
\text { industry; inexperienced }\end{array}$ \\
\hline Mode of entry & $\begin{array}{l}\text { Branching: local diversification; } \\
\text { dedicated spinoff. Branch evolution: } \\
\text { dedicated spinoff }\end{array}$ & $\begin{array}{l}\text { Branching: new business start-up; } \\
\text { subsidiary foreign company. Branch } \\
\text { evolution: local diversification }\end{array}$ \\
\hline $\begin{array}{l}\text { Motive of entry \& market } \\
\text { position }\end{array}$ & $\begin{array}{l}\text { Market for niche product; exploiting } \\
\text { specific knowledge or knowledge in } \\
\text { related activities }\end{array}$ & $\begin{array}{l}\text { Current general local demand; } \\
\text { general sector or business knowledge }\end{array}$ \\
\hline $\begin{array}{l}\text { Absorptive capacity } \\
\text { technology standards }\end{array}$ & $\begin{array}{l}\text { Branching: present } \\
\text { Branch evolution: high; highly } \\
\text { educated, skilled, and experienced } \\
\text { employees dedicated to business } \\
\text { line; high proximity to state of the } \\
\text { art in the industry }\end{array}$ & $\begin{array}{l}\text { Branching: not present } \\
\text { Branch evolution: low; less educated, } \\
\text { skilled, and experienced employees } \\
\text { working in multiple business lines; } \\
\text { low proximity to state of the art in } \\
\text { the industry }\end{array}$ \\
\hline $\begin{array}{l}\text { Competences/capabilities } \\
\text { employees }\end{array}$ & High; much attention to training & Low, little attention to training \\
\hline
\end{tabular}

\begin{tabular}{|c|c|c|}
\hline Customer range & $\begin{array}{l}\text { Broad, substantial effort in widening } \\
\text { customer range with products }\end{array}$ & $\begin{array}{l}\text { Narrow, little effort in widening } \\
\text { customer range with products; } \\
\text { passive }\end{array}$ \\
\hline $\begin{array}{l}\text { Way serving clients } \\
\text { (product customization) }\end{array}$ & $\begin{array}{l}\text { Branching: customization } \\
\text { Branch evolution: higher level of } \\
\text { standardization and innovative; } \\
\text { niche product yet avoidance high } \\
\text { asset specificity; }\end{array}$ & $\begin{array}{l}\text { Branching: high level of } \\
\text { standardization } \\
\text { Branch evolution: customization; } \\
\text { customer-driven; risk of high asset } \\
\text { specificity; little own innovation }\end{array}$ \\
\hline $\begin{array}{l}\text { Firm/enterprise } \\
\text { organization }\end{array}$ & $\begin{array}{l}\text { Branch evolution: narrow product } \\
\text { portfolio organized in single } \\
\text { business entity; proprietor managed } \\
\text { or part of multi-locational or } \\
\text { international organization }\end{array}$ & $\begin{array}{l}\text { Branch evolution: broad product } \\
\text { portfolio organized in multiple } \\
\text { business entities; bundle of } \\
\text { businesses; part of 'conglomerate- } \\
\text { like' organization }\end{array}$ \\
\hline $\begin{array}{l}\text { Strategic intent and } \\
\text { dedication }\end{array}$ & $\begin{array}{l}\text { Active; long term commitment to } \\
\text { business line; central in strategy } \\
\text { aimed at building competitive } \\
\text { company, serving customers in } \\
\text { range of industries }\end{array}$ & $\begin{array}{l}\text { Passive; short term results and profit } \\
\text { driven; no long term commitment; } \\
\text { easy switch to business lines with } \\
\text { higher return at short term }\end{array}$ \\
\hline $\begin{array}{l}\text { Investment inclination } \\
\text { and potential }\end{array}$ & High, deep pockets & $\begin{array}{l}\text { Low, little commitment and means; } \\
\text { spread of resources }\end{array}$ \\
\hline $\begin{array}{l}\text { Entrepreneurial lens and } \\
\text { human capital }\end{array}$ & $\begin{array}{l}\text { Innovative; cognitive perception of } \\
\text { opportunities; programs for } \\
\text { retaining skilled employees; high } \\
\text { employee remuneration; high } \\
\text { employee loyalty }\end{array}$ & $\begin{array}{l}\text { Follower; little cognitive perception } \\
\text { of opportunities; few programs for } \\
\text { retaining skilled employees; average } \\
\text { employee remuneration; high } \\
\text { employee turnover }\end{array}$ \\
\hline
\end{tabular}

Source: own draft 
some firms evolve better than others (see also KOCK/GUILLÉn 2001; LeE KeUn 2010, KIM/ LeE Keun 2003; König/STEPhan 2007; SunG/ CARLSSON 2003).

Industries marked by low level product and process technology or product and technological heterogeneity with segments requiring little innovation at inception, and by a diverse technological regime are more likely to emerge from branching. Tab. 2 lists circumstances conducive to, or hampering, positive evolution. According to LEE KEUN (2010), technological upgrading in late-industrializing countries is difficult with respect to technology- and innovation-based industries as these are marked by a concentration of capability, resources and markets in a few firms. As these dominate the industry and are able to shift the technological frontier at substantial speed, the relation between demand and innovation transits to supply-driven. They capture a large part of global higher- and front-end markets, leaving opportunities for other firms only in middle- to lower-end and back-end segments while at the same time confronting catch-up firms with a distance or gap to the technological frontier that is extremely hard to bridge. He postulates that the larger the gap with the technology frontier, the more this acts against technological effort. KÖNIG/STEPHAN (2007) hold that such proposition is relevant especially for complex systemic industries.

Tab. 3 lists the main factors at the firm level, and differentiates circumstances related to these factors that are conducive from those that constitute liabilities. The literature (e.g. CARMEY/GedAJlovic 2002; KocK/GuILLÉN 2001) shows how in the Southeast Asian context the institutional environment has given rise to distinct forms of business organization, especially among local Chinese business, such as family business groups often with a diverse business portfolio. Such organization impacts entrepreneurial commitment to specific business lines and strategic intent. BUENSTORF (2007), FRITSCH/ SCHINDELE (2010) and SANTARELLI/ VIVARELLI (2007) highlight the entrepreneurial foundations of perception, motivation, strategic choices and action. Entrepreneurs are heterogeneous; they include innovators, active imitators and success-seekers, passive followers, (over-)optimist gamblers and escapists. Thus one can expect differential post-entry performance. In addition, motivation, percep- tion, and strategic choice may change over time, in part associated with the degree to which ex-ante expectations are met in the early phase. SantarelLi/Vivarelli (2007) refer to so-called revolving door firms that enter and exit lines of business and close/re-open firms easily.

\section{Methodology and data}

The automation industry is one of the most recent industries in the supply complex linked to Penang based multinational corporations. Although by the mid-2000s this industry had become sizeable, little was known about it. A review of industrial policy pursued at the time in Penang reveals that the industry was not targeted for state-guided development. Its apparent growth notwithstanding lack of state attention prompted a study in 2005 to unravel the industry's development story. ${ }^{1}$ The first step taken was an inventory of firms in the industry. The industry was defined as producers and/or designers of automated full equipment and/or systems for industrial purposes; automation does not necessarily have to be the main activity of the company but has to be a substantial part of at least ten percent of the output of the company. Application of criteria derived from this definition and related to products manufactured to a range of sources (amongst others listings of firms obtained from Penang Development Corporation, now known as InvestPenang, from the local Federation of Machinery Producers and others) produced 39 firm names in Penang state. These were contacted to verify their classification as industrial automation firms. A few had to be removed; the remainder were approached for an interview. This produced 28 interviews. It should be noted that the firms encountered in 2005 might not be the complete population at the time as firms not listed may have been overlooked while firms that had exited the industry before 2005 were not traceable.

In 2011 a follow-up study was conducted comprising a second series of interviews to monitor the evolution of the industry. The firms concerned were the ones interviewed in 2005 and all others active in industrial automation in 2011. Following the same inventory procedures as in 2005 we arrived at 33 firms. Of these, 16 interviews were obtained, which included 15 of the firms in the 2005 study. Al- 
Tab. 4: Characteristics of the automation firms in Penang 2005

\begin{tabular}{|c|c|c|c|c|c|c|c|}
\hline Firm & $\begin{array}{l}\text { Origin } \\
(\mathrm{F}=\text { foreign; } \\
\mathrm{L}=\text { local })\end{array}$ & $\begin{array}{l}\text { Diversifier/ } \\
\text { Core (de } \\
\text { novo) }\end{array}$ & $\begin{array}{l}\text { Total } \\
\text { employees } \\
\text { company }\end{array}$ & $\begin{array}{l}\text { Number of } \\
\text { employees } \\
\text { automation } \\
\text { at start }\end{array}$ & $\begin{array}{l}\text { Number of } \\
\text { employees } \\
\text { automation }\end{array}$ & $\begin{array}{l}\text { Share of } \\
\text { automation } \\
\text { in turnover } \\
(\%)\end{array}$ & $\begin{array}{l}\text { Mode of } \\
\text { production } \\
\text { ( } \mathrm{S}=\text { standard; } \\
\mathrm{C}=\text { custom; } \\
\mathrm{B}=\text { both) }\end{array}$ \\
\hline $1^{*}$ & $\mathrm{~F}$ & $\mathrm{C}$ & 30 & 50 & 30 & 100 & $\mathrm{~S}$ \\
\hline 2 & $\mathrm{~F}$ & $\mathrm{C}$ & 50 & 4 & 50 & 100 & $\mathrm{~S}$ \\
\hline 3 & $\mathrm{~L}$ & $\mathrm{C}$ & 90 & 13 & 90 & 100 & B \\
\hline 4 & $\mathrm{~L}$ & $\mathrm{D}$ & 300 & 5 & na & 100 & B \\
\hline 5 & $\mathrm{~L}$ & $\mathrm{D}$ & 350 & 3 & 130 & 80 & $\mathrm{~S}$ \\
\hline $6^{*}$ & $\mathrm{~L}$ & $\mathrm{D}$ & 60 & 3 & 20 & 50 & C \\
\hline $7 *$ & $\mathrm{~L}$ & D & 70 & 2 & 15 & 35 & $\mathrm{C}$ \\
\hline $8 *$ & $\mathrm{~L}$ & $\mathrm{D}$ & na & 3 & 4 & 15 & $\mathrm{C}$ \\
\hline 9 & $\mathrm{~L}$ & $\mathrm{C}$ & 15 & 3 & 15 & 100 & C \\
\hline 10 & $\mathrm{~L}$ & $\mathrm{D}$ & na & 15 & 175 & 100 & S \\
\hline 11 & $\mathrm{~L}$ & $\mathrm{D}$ & 20 & 10 & 15 & 80 & $\mathrm{C}$ \\
\hline $12 *$ & $\mathrm{~L}$ & $\mathrm{D}$ & 300 & 9 & 200 & 80 & $\mathrm{~S}$ \\
\hline 13 & $\mathrm{~L}$ & $\mathrm{C}$ & 40 & 3 & 40 & 100 & C \\
\hline 14 & $\mathrm{~L}$ & D & 21 & 4 & 15 & 60 & C \\
\hline 15 & $\mathrm{~L}$ & $\mathrm{C}$ & na & 5 & 25 & 50 & $\mathrm{C}$ \\
\hline $16^{*}$ & $\mathrm{~L}$ & $\mathrm{C}$ & 15 & 2 & 15 & 100 & $\mathrm{C}$ \\
\hline 17 & $\mathrm{~L}$ & $\mathrm{D}$ & 100 & 2 & 10 & na & C \\
\hline $18^{*}$ & $\mathrm{~L}$ & D & na & 10 & na & 30 & $\mathrm{C}$ \\
\hline $19 *$ & $\mathrm{~L}$ & $\mathrm{D}$ & 60 & 6 & 60 & 100 & B \\
\hline $20 *$ & $\mathrm{~L}$ & $\mathrm{C}$ & 150 & 4 & 150 & 100 & B \\
\hline $21 *$ & $\mathrm{~L}$ & $\mathrm{D}$ & 60 & 5 & 10 & 30 & $\mathrm{C}$ \\
\hline $22 *$ & $\mathrm{~L}$ & $\mathrm{D}$ & 60 & 4 & 40 & 70 & $\mathrm{C}$ \\
\hline $23 *$ & $\mathrm{~L}$ & $\mathrm{C}$ & 48 & 3 & 48 & 100 & B \\
\hline $24 *$ & $\mathrm{~L}$ & $\mathrm{D}$ & 240 & 6 & 15 & 30 & B \\
\hline 25 & $\mathrm{~L}$ & $\mathrm{C}$ & 60 & 4 & 60 & 100 & B \\
\hline $26^{*}$ & $\mathrm{~L}$ & $\mathrm{D}$ & 70 & 8 & 20 & 48 & $\mathrm{C}$ \\
\hline $27^{*}$ & $\mathrm{~L}$ & D & na & 20 & 35 & 10 & $\mathrm{~S}$ \\
\hline 28 & $\mathrm{~L}$ & $\mathrm{D}$ & $\mathrm{Na}$ & 10 & na & na & C \\
\hline
\end{tabular}

na $=$ not available, $*$ cooperated in both surveys

Source: own survey

though response rate was lower, the firms interviewed were quite representative of the population. To maintain confidentiality, firm names are not displayed or mentioned. Interviews conducted were guided by a questionnaire. To ensure comparability, questionnaires administered in both 2005 and 2011 covered more or less identical aspects. Information was elicited about the following: structure and origin of the company, automation as a business in the company, history and current characteristics of the product portfolio of the automation business in terms of products, markets, clients, size and growth; competences / capabilities, learning and technology development; and asset strategy, performance determinants and overall company strategy. In the second survey, networking and knowledge exchange were also included as an item. We report on selected survey findings. Besides industry survey, open interviews with local industry experts from several organizations constituted another important source of information.

\section{The emergence of Penang's automation industry}

The discussion in this section covers - in industry life cycle terms - the birth and initial development period of the industry. In contrast to a number of other industries in Penang and 
Fig. 1: Automated equipment firms in Penang: start of automation activities relative to start of the company

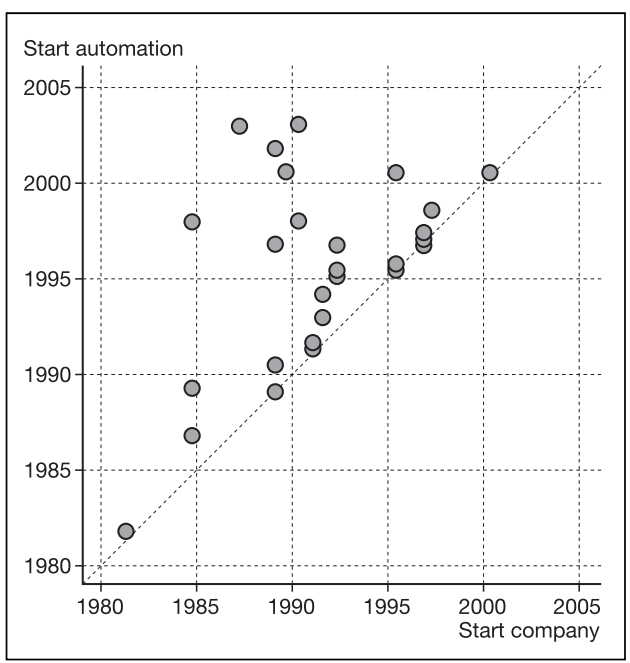

Source: own survey

Malaysia (BunNell 2004; JoMo 2003; Jomo et al. 1999; RASIAH 1999, 2001a, b) the development of the automation industry in Penang can be likened to an evolutionary branching process of local firm development.

Firms interviewed in 2005 had various backgrounds/origins. The survey revealed heterogeneity in terms of start, background of entrepreneur and growth. Of the 28 interviewed firms, only two were of foreign origin (Japan and Canada); the remainder were led by local Chinese - entrepreneurs. In two-thirds of the cases, entry into automation was through diversification from the existing product portfolio. The remaining cases (10) were de novo entrants. Generally firms had started very small, with fewer than five employees in automation activities. All but one of the largest (in terms of employment) operations at establishment were diversifying firms (Tab. 4).

The start of industrial automation by the diversifying firms was in most cases years later than the initial establishment of the firm (Fig. 1 shows the time lapse). The diversifying firms almost invariably originated from enterprises engaging in related areas: e.g. the production of machine tools and parts, metal components, precision components, jigs and fixtures. In some firms this is still the core business. In other cases automation has become the core business, but the other products are still part of the product portfolio. The de novo firms had a smaller range of activities. A few have grown rapidly from their establishment and had started to diversify within automation and beyond (involving less technologically advanced products). Most of the firm founders had gained experience prior to establishing the firm in a multinational company operating in the state (19 of the 26 local entrepreneurs). This concerned mostly the semiconductor industry, with Intel as the major source, followed by Motorola and Agilent.

Entrepreneurs organized their companies in multiple ways. A few diversifying firms still had a one-corporate entity structure. Reflecting the practice amongst local Chinese firms to organize lines of business in separate corporate entities, a large majority had a group structure in which multiple entities functioned under one holding company (Fig. 2 depicts such a structure, showing automation as a separate business entity in a firm having five branches).

For these firms, entry into industrial automation was often client-driven. Diversification occurred because of demand from buyers of their other products. Hence, 15 firms produced on a custom basis and were highly customeroriented, seven were producing custom and some standard products, and just six produced standard products only. De novo firms more often had a one-corporate-entity structure; yet three had assumed a group structure. A higher percentage of de novo firms produced standard products $(60 \%)$ compared to the diversifying firms $(39 \%)$. The information obtained about the background of de novo firms, their founders and their automation business lends support to a co-evolutionary process of - and within - local support industry with local operations of selected multinational companies in a number of industries. Employee start-up through spinoff from these companies has been a major mechanism whereby a relatively small number of hub firms spawned the majority. Clients already buying lower-end products drove the later-stage diversification process. 
Fig. 2: Group structure of a diversified company with the production of automated equipment as one of the entities

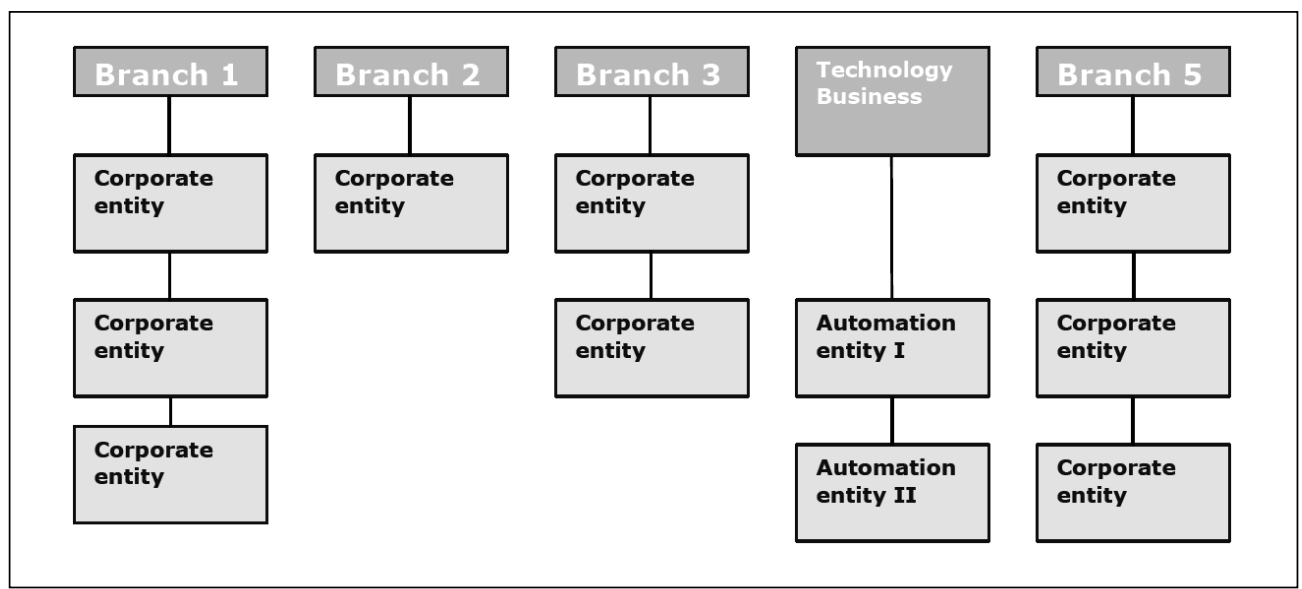

Source: own draft

\section{Determinants of branching}

We now turn to the main determinants of branching in the local context with reference to the framework developed above. Starting with the industry level, in relation to features depicted in Tab. 2 the industrial automation industry is a heterogeneous one characterized by product heterogeneity, small production volumes, a variety of markets, varying technology content, and products that integrate technologies from a range of applications. While standardization is possible across industry markets by employing common technology platforms (transferability of configurations, capabilities and expertise), differentiation is evident according to (1) level of customization (fully custom vs. standard production), (2) operations whereby assembly is least capability demanding while extension to design and system/software integration based on own research and development (R\&D) and innovation requires high technological competence, (3) technological complexity ranging from low-end to mid- and highend, (4) links in the process chain of client industries, ranging from back-end or downstream to front-end or upstream; generally it can be said that a shift from back-end to midand front-end adds to technological complexity and thus capability requirement of constituent firms of the industry. Differential combinations produce varying levels and patterns of specialization. Depicted as a support industry, the drivers in terms of the roles of automation in the product cycle and processes of client industries are several. Automation that is directed to back-end processes, involving a high degree of custom assembly, situated at the low end of the technology scale with little own design or development requirements is most extreme driven by efficiency or product cost considerations of client firms. Thus, price is an important competitiveness factor. Automation that is directed towards mid- and front end processes, that moves away from custom to standard machinery, developed through own innovation achieved through assembly of substantial technological resources whereby design is an important activity demanding high technological capability tends to assist and enable client industries to innovate new products and processes. Such a role as co-developer, which is still customer- yet more supply-driven, hinges on technological innovation 'power' as the main competitiveness factor. These two drivers are extremes in a spectrum of possibilities, whereby there is a range of combinations such as back-end processes yet high-end technology content. In some segments of the industry technology development is rapid, and while the 'standard' was technologically manageable to newcomers in the past, this may now less be the case. In the most sophisticated segment the technology frontier is moving that fast that catching-up to market leaders is an uphill task indeed. In lower segments technology development appears to be slow. 
These industry characteristics allowed entry at a low level by serving the low-end segment of back-end process equipment for the local semiconductor industry. For diversifiers this revolved around customized turnkey equipment. Shifting to the level of the region, this local market potential tied in with the earlier growth of a sizeable supply industry. Both are interwoven with the influx of overseas MNC since the 1980 s, many active in semiconductor and consumer electronics markets. Propelled by demand from MNC the prior foundation of firms in linked support industries partly underlies the branching story. Significantly, RASIAH (1999, 2001a, 2001b, 2002) has emphasized the role of systemic coordination in the emergence of the Penang electronics industry and the support industries during the $1980 \mathrm{~s}$ and $1990 \mathrm{~s}$, the latter through the heralded program of linkage between MNC and local industry. The program not only fostered relations between foreign firms and local industry, but also substantial goodwill of foreign firms towards local industry stimulating not only demand but also assistance in capability development. Interviewees expressed that this goodwill still prevailed at the time of genesis of automation and was a factor for firms to enter the path as by then institutional coordination had been virtually abandoned (as noted by many interviewees). When MNC in Penang started to automate their processes, goodwill translated into extension of local demand into automation products. Generally, local entrepreneurship has worked in symbiosis with selected hub firms in the local base of MNC that developed a significant presence in Penang from the 1990s.

The latter has been promoted also by some favourable circumstances at the level of the firm, namely expertise of founders and capabilities in relation to market demand. De novo firms were able to transfer entrepreneurs' product and technological knowledge to their own firm providing the basis for development of specialization in the form of niche products. They could take on opportunities in the local market allowing them to be more product-oriented. Many diversifying companies could start out with simple machines/systems in terms of technological content, design, and systems integration. Extension to automation products was possible for the firms because the capabilities needed were related to existing ones. As such learning was rather fast, and capability development was incremental. Thus we note the foundation of capability developed from related variety. This foundation has been enhanced in the initial phase of evolution after entry. Many firms in 2005 rated core-capabilities as medium or a little above. Notably, a substantially larger proportion of de novo firms disagreed with the proposition that capabilities are rather shallow and narrow. Many firms expressed that clients had played a role in upgrading core-capabilities to the level of being able to handle clients specifications. Most often, learning had occurred intra-firm by doing, discussing product specifications and technical matters in meetings, and inhouse training. Inter-firm knowledge exchange had not played a role.

\section{The evolution of Penang's automation industry}

This section discusses the evolution of the industry between 2005 and 2011, based on the 2011 data. Although still young, some dynamic trends were evident in the industry in 2005. These included: 1) technological composition of the product portfolio, 2) type of products, 3) geography of markets, 4) type of markets, and $5)$ interfirm coordination. The position of most firms, including de novo ones, in the industry could be characterized as geared towards serving lower end segments of machine markets for back-end processes, on the basis of client-driven custom production with little demand for design capability requiring deep technological knowledge with a majority of local clients in a few dominant industries indicated above. However, a few firms in their product portfolio had moved to or focused on more complex and/or standard machines/systems, including own design and own brand manufacturing. A counter-development that was evident also in firms was branching into other activities (related and unrelated) as they grabbed any local growth opportunities. Quite a few companies had started to export, varying from as much as $80 \%$ to as low as only $10 \%$ of output. An important qualification to be made is that at that particular time export was mostly associated with MNC in client industries expanding elsewhere in the region. Maintaining a focus on back-end processes, companies had begun to search for market diversification to inter alia the medical devices industry, opto-electronics, photonics and others. In 2005 the industry and the state government (in the form of Invest Penang) formed the Penang Automation Clus- 
ter as a agency for coordination and collaboration in this area. This industry platform was still in its infancy at the time of the first survey.

From these observations growth prospects of the industry in Penang appeared rather positive, although mixed. Unfortunately, in the 2011 follow-up it proved not possible to gain insight into industry trends from local statistical data. Not only statistical data (on number of firms, turnover, employment, value added, exports, and so on) are hardly collected and published, whatever aggregate secondary data are available suffer from definition and demarcation problems, such that the automation industry cannot be isolated as a separate category. The latter also goes for the irregular industry surveys. Our own population analysis as part of the 2011 research revealed that out of the 39 firms encountered in 2005, two had merged or had been taken over by a foreign company that had entered after 2005. No less than eight firms were no longer in operation in Penang. One has fully relocated and is now active in China only. Strikingly, the other seven firms could be established as exits. Four of these had been interviewed in 2005. As they could not be interviewed, all that can be said is that these firms were heterogeneous as to origin/emergence, defying common explanation as to why they failed. Equally striking, new entry into the industry after 2005 proved negligible as only one firm, apart from the one mentioned above, was found. Thus, the population in 2011 amounted to 33. As this is less than the number in 2005 (39) it can be established that the branch has shrunk rather than grown thicker. Most expert interviewees shared the view that the lack of new entries can be explained from the fact that the drivers that propelled the industry prior to 2005 - Penang still being significantly a production platform for $\mathrm{MNC}$, increasing automation of production processes by locally established MNC in several industries, thus substantial local demand, and earlier mentioned factors - largely had dwindled towards the end of the 2000s. Having to engage in export from the start constituted too large a barrier for possible new start-ups.

The firms that participated in the 2011 survey were mostly stayers and represented some $60 \%$ of this category. Contrary to expectations, the findings among the firms that participated in both surveys showed that firms that have experienced a decline in the share of au- tomation products in turnover far outnumber those that have experienced an increase. Such decline ranges from 10 to $20 \%$ to as much as 40 to $50 \%$. However, this does not say anything about the absolute development of automation business at company level. Changes in the number of employees in the automation business (2011 compared to 2005 and start) and annual turnover (2010 compared to 2004) reveal performance bifurcation. Evidently, the branch has split into two sub-branches: growers and stagnating firms. Three firms had shed employees since 2005. Two of these showed negative development of turnover. Both classified in 2005 as de novo entry, they are different however in size and structure. One is a small firm with a simple organization structure, the other was in 2005 showcased as a success story in the industry having developed into one of the largest firms. Yet on average de novo firms had not performed negatively and worse than diversifiers. Almost the contrary is true. The third case, a diversifier, had experienced a small $10 \%$ growth. Stagnating firms still produced mostly on a custom basis.

On the other hand a small number of firms had experienced a healthy growth in the number of employees. The strongest grower - with a de novo background - is active in a niche market. The firm ranked second in growth had opened subsidiaries in Thailand and China. The common denominator among the top five employment gainers is that they have developed new products; one has always produced standard equipment only while some others have moved into the standard market under own brand name and patented product innovations. Six firms experienced a decline in the turnover of their automation products; four of these even described a 'strong decline'. For three firms turnover remained the same; five firms indicated an increase. Only two firms indicated rather fast growth. Turnover has slowed down notwithstanding many (11) firms having experienced an increase in clients and order size. Evidently product prices have lowered resulting from market slowdown.

Evidently - and consistent with the reasons given for the lack of new entry into the industry - the importance of Penang when it comes to clients of the industry has declined. The most successful firm by 2011 had only a very low share of clients in Penang (5\%), having developed strong export capability on the basis of its 
innovative niche products. Thus the industry has become increasingly dependent on exports.

As branch development in the second half of the 2000s stalled, also overall the positioning of the Penang automation industry - with respect to the spectrum of industry features discussed earlier - has remained largely unaltered. This is evidenced by continued focus on production in the low-end segment, a widening gap with the average technological level in the global industry, low intent to invest in new products or building equipment according to innovative designs, and on average the small share of resources that firms devote to product development, design, integration, and especially research and development. By 2011 six of the interviewed firms produced under their own brand. As custom production is still the main production mode in the industry, patenting of $R \& D$ results/innovations is limited to just four firms. These are amongst the six firms producing own brand products. The exceptions to the rule point towards bifurcation in evolution as market strategies, product portfolio, and the intent to standardize and innovate are dissimilar according to background, mode of entry, and market focus. While the average amounted to less than $15 \%$ of staff dedicated to research and development, bifurcation can be seen here whereby a few firms show substantial emphasis as opposed to many firms 'scoring' very low.

\section{Interpreting growth and stagnation}

We attempt a preliminary interpretation of these features from the three-dimension framework (Tab. 1-3). Some observations can be made as to factors at the industry level. While transferability allows market diversification this is so predominantly at the low-end of the technological scale. Tapping new industries as markets therefore only goes so far as far as value creation is concerned. Technological development in products of client industries proceed and push processes further along the technological scale, requiring the industry in general to follow technological developments closely. Firms that are capable to do so are generally located in advanced countries and have been in the best competitive position to capture markets for standard, mid- to higher end products oriented to mid- and front end processes. This has produced significant market-segment entry problems as these firms have been sought after as preferred supplier by major firms in client industries. So far the latter - be they located in Penang/Malaysia or elsewhere - have looked towards Penang for low end products based on price.

As most Penang firms have not proven advanced capabilities a market lock-in has been looming. It seems there is no escape from this (and customer cognitive bias) until there is a deliberate industry-wide attempt at shift of position from customized to standard, from lowend to mid and higher-end, from assembly to design and integration orientation. However, this would require substantial efforts and investments as to technology input, product and process innovation, learning and capability development. An alternative path of focus on own brand products in new niche market(s) or towards better position in niches equally requires such efforts and investments.

In terms of firm-level characteristics, one explanation why only a small group of firms have made substantial achievements here so far is the size of automation operations hardly passing the critical mass prompting such investment. More commonly this is the case for diversifiers. Still having substantial business in tool and die, precision tooling, machine parts and engineering, the majority of these firms are primarily oriented towards keeping a diversified product portfolio with a view to reaping short-term returns by shifting business to the most profitable products. Slow progress in this group between 2005 and 2011 with regard to producing more value added products signals spread of investment resources and inward-oriented capability development.

Complicating this are issues at the level of the region, namely market, resources to address product quality deficiencies and to engage in design and research and development, and coordination with respect to the institutional and technological environment. As markets have broadened since 2005 (with food, LED, electronics, hard disk drive, medical devices, automotive and energy as new opportunities) dependence on the semiconductor industry has diminished. However, the maximum shares of medical devices and LED in turnover encountered in the 2011 survey amounted to $25 \%$ and $30 \%$ respectively. As MNC in a range of industries have started to relocate production to 
elsewhere local demand from firms in established industries has declined. While by 2011 still half of the surveyed firms obtained their main share of turnover from the semiconductor market this market has been dwindling the last few years as the industry underwent restructuring and downsizing in response to the impact of the global downturn of 2008 to 2010 . In Penang, Intel Corporation in 2009 closed down two of its three assembly plants (The Star 2009). Intel Penang was a major client of the local automation industry. As the semiconductor industry in Penang shifted emphasis to product development local demand for higherend equipment has not materialized.

Entering into yet newer markets locally is not smooth for most firms. While new MNC still come in, either their operations do not require automated equipment or their production is already highly automated, as a result of which in the first instance they bring in core equipment and technologies acquired abroad. Thus, overall the local market in Penang has become rather exhausted. The avenue of exports is an equally doubtful one. So far exporting firms (all but one) mostly serve the Asian market. A higher share of exports mostly reflects customers that have relocated from Penang but that still place orders. Retaining these customers has become increasingly difficult as suppliers of custom yet generic low-end equipment are equally available at the new location and Penang suppliers appear to lack a specific competitive advantage. As the exception appears to be niche products produced by a few firms that owe their success to being innovative in their own brand equipment expanding and deepening exports runs exactly into the problem that many firms thought they could avoid by engaging into foreign markets.

As to resources, many firms see a severe deficiency of human capital possessing the required skills. As it is, the turnout of technical staff and engineers from the local educational institutions is still limited. Competing demand for technical staff and engineers from MNC has produced an ever more tight labour market as Invest Penang has continued to focus on attracting new firms. As knowledge workers often choose to work for foreign MNC, the local industry has difficulty in holding on to them to perform more value-added activities. Penang Automation Cluster (PAC) in 2008 stated that quality of locally produced automated equip- ment is compromised by insufficient capable suppliers in the region (The Star 2008). As to coordination, the formation of the PAC was a good step towards addressing the issues mentioned above by having a platform for interfirm collaboration in the industry and for industry-institutional coordination. However, PAC did not fulfil its aim as the initiative was rather short-lived: it went dormant after a few years of operation. Some of the reasons for this relate to its core membership and leadership, as well as its composition. Initial core membership and leadership was drawn entirely from the largest companies in the industry at the time, and this leadership showed little recognition of smaller firms. ${ }^{2}$ This raised suspicion in the industry as to the intent of the cluster leadership. Actors involved in practical deliberations in the cluster were mostly (larger) competing firms rather than potential external knowledge providers, relevant state institutional organizations, and so on, in addition to firms. This resulted in individual interest prevailing over collective interest.

Absence of inter-firm knowledge transfer and learning has not been compensated by systemic coordination in other ways involving the local state. Comparing earlier local state systemic coordination, what is most lacking perhaps is a concerted effort to coordinate the building of a properly functioning regional/local innovation system acting as a repository of technological know-how, learning base and focus of production of human capital relevant to the industry and to be tapped into by firms. HuTCHINSON $(2008,2010)$ has recently demonstrated that its structure is still extremely fragmented. The reasons for this are many. As Penang was looked at by local administration as a production platform for MNC, local firms/SME for a long time did not come into the picture other than as suppliers. As MNC were conceived as major and sufficient channels of technology acquisition and transfer, institutional arrangements in this area were deemed unnecessary. However, as we have indicated already at the same time as MNC have started to engage in restructuring resulting in technological upgrading ties between MNC and local SME are increasingly cut. The creation of a suitable environment for learning and innovation and collective action in these areas have been hampered significantly also by the development agenda of Penangs ruling political coalition which over the 2000 s has increasingly con- 
formed to national level responses to issues linked to Malaysia's ethnically plural society, i.e. affirmative action policy towards ethnic inequalities that bypasses the Chinese-owned manufacturing sector as MNC are a more neutral and less sensitive avenue to achieving some of the goals. This national context of Malaysia entering Penang state is rather unique to the case.

Coupled with customized mode of producing, and mainly internal channels for learning, the above render firms passive to upgrading capabilities, to pro-active investment in the development of products under own brand, and catering to the higher order demand of new clients. Most firms, especially those with a diverse portfolio of businesses, face a bi-directional causal relationship between lock-in in low-level technology confining them to lowend automation, hampered market diversification and constrained upgrading. A lack of coevolution in the technology and innovation area of industry with institutions translates into few inter-firm and industry-institutional spillovers and firms still relying on clients for knowledge, reinforcing the lock-ins.

However, additional factors at firm-level should be recognized also. Cognitive perception, tantamount to cognitive lock-in seems interwoven as indicated by, first, little outspoken opinions about the roles and functioning of the state. Second, limited views on technology requirements as innovative products and product innovation are not seen as key for success. According to the majority of interviewees the pace of technological changes since 2005 has been low. It is hard to ignore the impression that there is a segment of firms that do not have perceptions beyond the industry segment in which they operate, hardly developing a cognitive idea of the larger - global - picture of developments in the industry, market developments, technology standards and so on. This situation is in many cases inspired also by aversion to risk.

An outcome of market and segment lock-in, coupled with cognitive lock-in and the practice of opportunistic business diversification is significant path dependence in business operation. This is revealed in the response of firms to divert attention and resources to yet other - often unrelated - lines of business that promise (more) short-term returns as opportunities pre- sent themselves. Thus, a number of firms have recently engaged in product assembly work for third parties. Cases of assembly of medical devices or surgical equipment illustrate the unrelated nature. A connection though is that in some instances in-house assembled machines are used. Such response propagates a business model devised from limited strategic intent that emphasizes breadth of scope, as a deep strategy of innovation and capability development to absorb new technology with a view to shifting their position in automated products is not prioritized. However, a contrasting picture is presented by the - few - cases that have shown positive performance and clear growth, and have become success stories by a way of operation that highly diverges from the account above. Being de novo spinoffs, their way of operation has been marked by pioneering a niche and a strategy that involves developing own product under own brand name, supply-oriented and a fair degree of standardization, running their own innovation system by substantial investment in research and development/innovation and in human capital that results in regular product innovations beneficial to the market, a focused development path throughout, entering new markets with high-end high-technology products in their niche enabled by their adjustment and innovation capacity. The success cases are the proverbial exceptions that confirm the rule. They have a entrepreneurial and growth-oriented firm culture, a focused longerterm firm development vision and strategic intent in which deepening business in a niche through innovation is central to their competitiveness. They therefore avoid becoming a bundle of related and unrelated businesses. Their human capital approach promotes retaining competences and high capacity to absorb new technology. Further, these firms are less hindered by operation from limited cognitive perception/lock-ins associated with earlier developed branches in the company.

\section{Conclusion}

Penang's automation industry conforms well to regional branching as a mode of industry and firm genesis suggested by evolutionary economic geography. In one part it has branched out from core variety in the local SME-dominated supply industry, and in another part startups through spinoff from client industries have played a significant role. To understand 
branching in this late-industrializing context, Malaysia/Penang being a second tier NIC, we have developed a three-dimension framework, suggesting factors and promoting or inhibiting circumstances at the levels of industry, region and firm. Application of this framework to our case appears to produce a fair account of the conditions promoting branching in the context of Penang.

Based on how the industry was born vis-à-vis conceptual accounts of industry evolution, and indications from the 2005 survey, we expected positive growth of the population and of individual firms post-2005. However, the 2011 survey indicates that less than two decades after its emergence the development of the industry has stalled. However, within an overall picture of stalling performance, bifurcation has occurred as the branch has split into two subbranches. One sub-branch comprises stagnators that include - entities of - firms that are detached from the technology and market race and have recently been faced with outside competition in the low-end segments of the industry based on costs and prices. The second comprises a smaller number of growers that have become stable competitors in the middle and higher-end segment of the automation regional market (and beyond) on the basis of niche products and quality. Our three-dimensional framework was also meant to provide understanding of more or less successful evolution of a branch after emergence. We believe that confrontation of industry and firm-level findings from our research with this framework produces a good understanding of first, overall evolution, and second the heterogeneity in terms of performance in the industry lateron in the life cycle. As our conceptual and empirical exercise sheds light on the conditions, in lateindustrializing context, with respect to branching and evolution of a branched industry the framework could guide more empirical research in Penang and especially other late-industrializing spaces into industry evolution.

The analysis guided by the framework also points towards responses by firms, the industry and institutions to address issues that hamper positive evolution. The significance of the few - firms that have not gone into stagnation lies not only in being the exceptions that confirm the rule, but also in showing the way. This is not to argue that the ingredients of their growth path should or could be directly copied by other firms. Rather they demonstrate that in the case of Penang an environment marked by conducive industry-state systemic coordination and a functioning technology and innovation infrastructure that is more integrated and industry-relevant is long overdue. This can have a positive impact on the limited mind set that currently appears to beset operators in the industry.

\section{Notes}

1 The research assistance of Ms. Marscha Aaldering, Masters student in the Faculty of Geosciences, Utrecht University, in the 2005 study is gratefully acknowledged here, as well as local support provided by Prof. Goh Ban Lee who in 2005 was at the School of Social Sciences, Universiti Sains Malaysia. As for the 2011 study, local support from the Socio-Economic Research Institute (SERI), currently Penang Institute, is gratefully acknowledged.

2 Summer 2006, discussion with chairman and governing council of the Penang Automation Cluster.

\section{References}

Boschma, R./Frenken, K. (2009): Technological relatedness and regional branching. Utrecht. (Papers in Evolutionary Economic Geography, No. 09.07; Utrecht University, Urban and Regional Research Centre Utrecht).

Breznitz, D. (2005): Development, flexibility and R\&D performance in the Taiwanese IT industry. Capability creation and the effects of state-industry coevolution. In: Industrial and Corporate Change, (14)1, 153187.

Breznitz, D. (2007): Innovation and the state. Political choice and strategies for growth in Israel, Taiwan and Ireland. London.

BüNSTORF, G. (2007): Evolution on the shoulders of giants. Entrepreneurship and firm survival in the German laser industry. In: Review of Industrial Organization, (30), 179-202.

Bunnell, T. (2004): Malaysia, modernity and the multimedia super corridor. A critical geography of intelligent landscapes. London.

Carmey, M./Gedajlovic, E. (2002): The co-evolution of institutional environments and organizational strategies. The rise of family business groups in the ASEAN region. In: Organization Studies, (23)1, 1-29.

Dutrénit, G./ Teubal, M. (2010): Critical masses, coevolutionary processes and economic development. Aalborg. (Paper presented at the International Schumpeter Society Conference 2010, Aalborg, June 2010).

Fritsch, M./ Schindele, Y. (2010): Success or failure? Business-, industry-, and region-specific determinants of survival. A multi-dimensional analysis for German manufacturing. Aalborg. (Paper presented at the Inter- 
national Schumpeter Society Conference 2010, Aalborg, June 2010).

Haggard, S./Lim Pao Li/Ong, A. (1998): The hard disk drive industry in the Northern Region of Malaysia. San Diego. (The Information Storage Industry Center, Graduate School of International Relations and Pacific Studies, University of California).

Hira, A./ Morfopoulos, J./ Chee, F. (2012): Evolution of the South Korean wireless industry. From state guidance to global competition. In: International Journal of Technology and Globalisation, (6)1-2, 65-86.

Hutchinson, F.E. (2008): 'Developmental' states and economic growth at the sub-national level. The case of Penang. In: Singh, D./ Than, T.M.M. (Eds.): Southeast Asian affairs 2008. Singapore, 223-244.

Hutchinson, F.E. (2010): Shallow pockets but close to the action. Industrial policy at the sub-national level and the case of Penang. In: Ooi, K.B./ Lee, G.B. (Eds.): Pilot studies for a New Penang. Singapore, 57-109.

Jomo, K.S./ Felker, G./ RAsiaH, R. (Eds.)(1999): Industrial technology development in Malaysia. Industry and firm studies. London.

Jomo, K.S./ Felker, G. (Eds.)(1999): Technology, competitiveness and the state. Malaysia's industrial technology policies. London.

Jomo, K.S. (2001), Introduction: Growth and structural change in the second-tier Southeast Asian NICs. In: Jomo, K.S. (Ed.): Southeast Asia's industrialization. Industrial policy, capabilities and sustainability. Basingstoke, 1-29.

Jomo, K.S. (Ed.)(2003): Manufacturing competitiveness in Asia. How internationally competitive national firms and industries developed in East Asia. London.

KIM, C.W./ LEE, K. (2003): Innovation, technological regimes and organizational selection in industry evolution. A history-friendly model of the DRAM industry. In: Industrial and Corporate Change, (12)6, 1195-1221.

KIM, L. (Ed.)(1999): Learning and innovation in economic development. Cheltenham.

KIM, L. (2001): The dynamics of technological learning in industrialisation. In: International Social Science Journal, (53)168, 297-308.

KLEPPER, S. (2001a): The evolution of the US automobile industry and Detroit as its capital. Pittsburgh. (unpubl. paper, Carnegie Mellon University, USA).

KLEPPER, S. (2001b): Employee startups in high-tech industries. In: Industrial and Corporate Change, (10)3, 639-674.

KLEPPER, S. (2002): The capabilities of new firms and the evolution of the US automobile industry. In: Industrial and Corporate Change, (11)4, 645-666.

KlepPer, S./ MalerbA, F. (2010): Demand, innovation and industrial dynamics: an introduction. In: Industrial and Corporate Change, (19)5, 1515-1520.

Kock, C.J./ Guillén, M.T. (2001): Strategy and structure in developing countries. Business groups as an evolutionary response to opportunities for unrelated diversification. In: Industrial and Corporate Change, (10)1, 77-113.
KÖNIG, R./ STEPHAN, M. (2007): Market take-off in systemic industries. The early industry life cycle stage in the mobile payment industry. Marburg. (Discussion Papers on Strategy and Innovation 07-03; Philipps-University Marburg, Department of Technology and Innovation Management).

Lall, S./ Urata, S. (Eds.)(2003): Competitiveness, FDI and technological activity in East Asia. Cheltenham.

LeE, C.K./ SAXENIAN, A. (2007): Coevolution and coordination. A systemic analysis of the Taiwanese information technology industry. In: Journal of Economic Geography, (8) 157-180.

LEE KEUN (2010): What makes more successful and less successful technological catch-up. Analyzing ten latecomer countries. Aalborg. (Paper presented at the International Schumpeter Society Conference 2010, Aalborg, June 2010).

MalerbA, F. (2006): Innovation and the evolution of industries. In: Journal of Evolutionary Economics, (16), 3-23.

Masuyama, S./ Chia Siow Yue / van den Brink, D. (Eds.) (2001): Industrial restructuring in East Asia. Towards the $21^{\text {st }}$ Century. Singapore.

Mathews, J.A. (1999): A silicon island of the East. Creating a semiconductor industry in Singapore. In: California Management Review, (41)2, 55-78.

RASIAH, R. (1999): Government-business coordination and the development of Eng Hardware. In: Jomo, K.S./ Felker, G./ Rasiah, R. (Eds.): Industrial technology development in Malaysia. Industry and firm studies. London, 231-246.

RASIAH, R. (2001a): Politics, institutions and flexibility. Microelectronics transnationals and machine tool linkages in Malaysia. In: Deyo, F.C./ Doner, R.F./ Hershberg, E. (Eds.): Economic governance and the challenge of flexibility in East Asia. Lanham, 165-190.

RASIAH, R. (2001b): Government-business coordination and small business performance in the machine tools sector in Malaysia. Washington. (World Bank Institute).

RASIAH, R. (2002), Systemic coordination and human capital development. Knowledge flows in Malaysia's MNC-driven electronics clusters. Tokyo. (UNU-INTECH Discussion Paper Series, \#2002-7).

SANTARElli, E./ Vivarelli, M. (2007): Entrepreneurship and the process of firm's entry, survival and growth. In: Industrial and Corporate Change, (16)3, 455-488.

SunG, T.K./ CARLsSON, B. (2003): The evolution of a technological system. The case of CNC machine tools in Korea. In: Journal of Evolutionary Economics, (13), 435-460.

The Star (2008): Call for state to lure foreign SMEs. Monday April 7, 2008. Internet: http:/biz.thestar.com/ $\mathrm{my} /$ news/story.asp? file $=/ 2008 / 4 / 7 /$ business $/ 200804070$ $71552 \& \mathrm{sec}=$ business

The Star (2009): Intel to close two Penang plants but no layoffs. Friday January 23, 2009. Internet: http:// thestar.com.my/news/story.asp? file $=/ 2009 / 1 / 23 /$ nation $/ 309$ $2979 \& \mathrm{sec}=$ nation 
Wenting, R./ FrenKen, K. (2011): Firm entry and institutional lock-in. An organizational ecology analysis of the global fashion design industry. In: Industrial and Corporate Change, (20)4, 1031-1048.
Zysman, J./ Doherty, E. (1995): The evolving role of the state in Asian industrialization. Berkeley. (BRIE Working Papers, No. 84. Berkeley; Berkeley Roundtable on the International Economy). 